\title{
KEPASTIAN HUKUM PENERBITAN SERTIFIKAT HAK KOMUNAL SEBAGAI PELAKSANAAN REFORMA AGRARIA SAFRIN SALAM ${ }^{1}$
}

\begin{abstract}
Abstrak
Keberadaan sertifikat hak komunal untuk menjamin kepastian hukum atas penguasaan tanah adat oleh masyarakat adat merupakan sebuah reforma agraria melalui terobosan hukum yang progresif. Namun dalam perkembangannya keberadaan sertifikat hak komunal masih perlu direvisi dan disesuaikan prinsip-prinsip pembaruan agrarian dengan memperhatikan kaidah-kaidah yang ada dalam Undang-Undang No. 5 Tahun 1960 sebagai induk dari aturan pertanahan. Hak komunal harus dikonsepsikan sebagai konsep hak milik yang bukan hanya bersifat public tapi juga privat.

Kata Kunci : Kepastian Hukum, Hak Komunal, Reforma Agraria
\end{abstract}

\begin{abstract}
The existence of communal rights certificates to ensure legal certainty over customary land tenure by indigenous peoples is agrarian reform through progressive legal breakthrough. But in its development where the certificate of communal rights still need to be revised and adapted the principles of agrarian reform by attention to the rules contained in Law No. 5 of 1960 as the fundamental rules of the land. Communal rights should be conceived as a concept of property rights is not only public but also private nature.

Keywords: Rule of Law, Communal Rights, Agrarian reform
\end{abstract}

${ }^{1}$ Dosen Fakultas Hukum Universitas Muhammadiyah Buton 


\section{Pendahuluan}

Instrumen pendaftaran tanah yang berlaku sekarang belum mengakomodasi keragaman tenurial di masyarakat hukum adat yang bersifat komunal. PP No. 24 Tahun 1997 tentang pendaftaran tanah, begitu juga PP No. 10 tahun 1961 yang berlaku sebelumnya, belum mampu memecahkan persoalan sertifikat tanah-tanah milik bersama yang merupakan ciri khas masyarakat hukum adat. Ketentuan ini justru ingin menyeragamkan bentukbentuk tenurial di seluruh Indonesia dengan menentukan jenis-jenis hak atas tanah yang bisa disertifikasi.

Walaupun demikian, kebijakan pendaftaran tanah di daerah tetap menunjukan variasi dalam mengakomodasi jenis-jenis tanah adat yang ada. Lahirnya Peraturan Menteri Agraria dan Tata Ruang / Kepala Badan Pertanahan Nasional No. 9 tahun 2015 Tentang Tata Cara Penetapan Hak Komunal Atas Tanah Masyarakat Hukum Adat Dan Masyarakat Yang Berada Dalam Kawasan Tertentu yang terbit tanggal 12 Mei 2015. Perka BPN No. 9 Tahun 2015 ini menjawab tuntutan hak masyarakat adat atas penguasaan tanah adat di seluruh Indonesia. Permen ini terbit untuk memenuhi tersedianya suatu pedoman sebagai pelaksanaan Peraturan Bersama Menteri dalam Negeri RI, Menteri Kehutanan RI, Menteri Pekerjaan Umum RI, dan Kepala Badan Pertanahan RI No. 79 Tahun 2014 tentang tata cara penyelesaian penguasaan tanah yang berada dalam kawasan hutan, khususnya untuk tanah-tanah masyarakat hukum adat. ${ }^{2}$

Perka BPN No. 9 tahun 2015 telah menggantikan Perka BPN No. 5 tahun 1999 tentang Pedoman penyelesaian masalah hak ulayat masyarakat hukum adat. Pengaturan "Hak Ulayat dan/atau Hak Komunal' oleh kedua aturan ini mempunyai konsep hukum yang berbadap dalam memaknai hak ulayat. Pada aturan Perka BPN No. 5 tahun 1999 masih menganut konsep Hak Ulayat, sebagaimana yang diatur dalam Pasal 1 ayat 1 dijelaskan bahwa Hak Ulayat dan yang serupa dari masyarakat hukum adat, (untuk selanjutnya disebut hak ulayat, adalah kewenangan yang menurut hukum adat dipunyai oleh masyarakat hukum adat tertentu atas wilayah tertentu yang merupakan lingkungan para warganya untuk mengambil manfaat dari sumber daya alam, termasuk tanah, dalam wilayah tersebut, bagi kelangsungan hidup dan kehidupannya, yang timbul dari hubungan secara lahiriah dan batiniah turun temurun dan tidak terputus dan tidak terputus antara masyarakat hukum adat tersebut dengan wilayah yang bersangkutan.

\footnotetext{
${ }^{2}$ Myrna Safitri. Mencari Perusak Hutan. Koran Kompas. Tertanggal 10 Maret 2015
} 
Konsepsi hak ulayat yang diatur dalam ketentuan tersebut bahwasanya hak ulayat merupakan hak turun temurun yang dimiliki oleh masyarakat hukum adat atas wilayah (sumber daya alam). Konsepsi hak ulayat diatur secara jelas dalam Undang-Undang No. 5 tahun 1960 Tentang Peraturan Dasar Pokok-Pokok Agraria dan selanjutnya disebut sebagai UUPA, Pasal 3 yang mengatur tentang "hak Ulayat". Dikarenakan hak ulayat merupakan hak turun temurun yang dimiliki oleh masyarakat hukum adat maka pengaturan penguasaan hak atas tanah terutama dalam proses pendaftaran tanah, objek tanah yang dikuasai oleh masyarakat hukum adat tidak diatur mengenai tanahtanah adat sebagai diatur dalam Pasal 9 PP No. 24 Tahun 1997 Tentang Pendaftaran Tanah. Sebagaimana yang dikatakan oleh Boedi Harsono, Hak ulayat merupakan serangkaian wewenang dan kewajiban suatu masyarakat hukum adat, yang berhubungan dengan tanah yang terletak dlam lingkungan wilayahnya, yang sebagai telah diuraikan di atas merupakan pendukung utama penghidupan dan kehidupan masyarakat yang bersangkutan sepanjang masa. Menurut pengertian ini, bahwa konsep hak ulayat yang diatur dalam ketentuan pasal 1 ayat 1 tersebut adalah hak ulayat meliputi semua tanah yang ada dalam lingkungan wilayah masyarakat hukum adat yang bersangkutan, baik yang sudah dihaki oleh seseorang maupun yang belum. ${ }^{3}$

Tidak diaturnya tanah adat sebagai objek pendaftaran tanah dalam PP No. 24 tahun 1997 Tentang Pendaftaran Tanah menimpulkan polemik hukum yang berkepanjangan mengenai kepastian hukum hak ulayat atas tanah yang dikuasai oleh masyarakat hukum adat. Dari perspektif UUPA, keberadaan tanah ulayat dan/atau tanah adat diasumsikan kedepan tanah ulayat akan hilang secara perlahan seiring dengan perkembangan zaman maka melalui ketentuan konversi yang dimuat dalam ketentuan-ketentuan konversi UUPA dari Pasal I sampai Pasal IX. Menurut Boedi harsono, mengatur hak ulayat dapat berakibat melanggengkan atau melestarikan eksistensinya. Perkembangan masyarakat menunjukan kecendurungan akan hapusnya hakhak ulayat melalui proses alamiah, yaitu dengan menjdi kuatnya hak-hak perorangan dalam masyarakat hukum adat yang bersangkutan. ${ }^{4}$

Terbitnya Perka BPN No. 9 tahun 2015 yang menggantikan Perka BPN No. 5 Tahun 1999 Tentang Pedoman Penyelesaian Masalah Hak Ulayat Masyarakat Hukum Adat, ingin mengatasi problematika kepastian hukum hak atas tanah oleh masyarakat adat dengan menerbitkan sertifikat hak komunal. Sertifikat hak komunal yang dikonesepsikan melalui Pasal 1 ayat (1) Perka BPN

\footnotetext{
${ }^{3}$ Boedi Harsono. 2008. Hukum Agraria Inonesia Sejarah Pembentukan Undang-Undang Pokok Agraria, Isi dan Pelaksanaannya. Penerbitan Djambaitan. Jakarta. Hlm. 186

${ }^{4}$ Ibid. hlm. 189
} 
No. 9 tahun 2015 dijelaskan bahwa hak komunal atas tanah, yang selanjutnya disebut hak komunal, adalah hak milik bersama atas tanah yang diberikan kepada masyarakat yang berada dalam kawasan hutan atau perkebunan. Pengertian hak komunal ini sangat tegas dan sifatnya sangat terbatas bahwa pemberian hak kepada masyarakat adat atas penguasaan tanah hanya yang berada dalam kawasan hutan baik hutan lindung maupun hutan produk. Definisi ini sangat jauh berbeda dengan hak ulayat yang diatur dalam ketentuan Perka BPN No. 5 Tahun 1999.

Kepastian hukum terhadap penguasaan tanah oleh masyarakat adat telah dijamin oleh UUPA, khususnya Pasal 19 Ayat (1) UUPA yang mengatur bahwa tujuan pendaftaran tanah yaitu untuk menjamin kepastian hukum. Pendaftaran tanah selain berfungsi untuk melindungi si pemilik, juga berfungsi untuk mengetahui status sebidang tanah, siapa pemiliknya, apa haknya, berapa luasnya, untuk apa dipergunakan dan sebagaianya. Apabila ditelesuri tujuan pendaftaran tanah yang diatur Pasal 19 Ayat (1) UUPA ditemukan pengaturan lebih konkrit bedasarkan pasal 3 Peraturan Pemerintah No. 24 Tahun 1997, tujuan pendaftaran tanah adalah

1. Untuk memberikan kepastian hukum dan perlindungan hukum kepada pemegang hak atas tanah dan hak-hak lain yang terdaftar agar dengan mudah dapat membuktikan dirinya sebagai pemegang hak yang bersangkutan;

2. Untuk menyediakan informasi kepada pihak-pihak yang berkepentingan termasuk pemerintah agar dengan mudah dapat memperoleh data yang diperlukan dalam mengadakan perbuatan hukum mengenai bidangbidang tanah yang sudah terdaftar;

3. Untuk terselenggaranya tertib administrasi pertanahan dimana setiap bidang tanah termasuk peralihan, pembebanan dan hapusnya hak atas tanah wajib terdaftar.

Dalam rangka memberikan kepastian perlindungan hukum, maka kepada pemegang hak atas tanah yang bersangkutan diberikan sertifikat hak atas tanah, sedangkan untuk melaksanakan fungsi informasi, data yang berkaitan dengan aspek fisik dan yuriddis dari bidang-bidang tanah yang sudah terdaftar, dinyatakan terbukti untuk umum (asas publisitas), sementara dalam hal mencapai tertib administrasi pertanahan, maka setiap bidang tanah ata satuan rumah susun, termasuk peralihan, pembebanan dan hapusnya hak atas tanah, dan hak milik satuan rumah susun wajib didaftar. ${ }^{5}$

\footnotetext{
5 Yamin Lubis \& Abd. Rahim Lubis. 2012. Hukum Pendaftaran Tanah. Penerbit CV Mandar Maju. Bandung. Hlm. 169
} 
Sertifikat merupakan jaminan kepastian hukum bagi pemegang hak atas tanah, kaitan dengan hal tersebut pada konteks penguasaan tanah adat dan/atau tanah ulayat, Negara telah merespon penguasaan tanah adat oleh masyarakat adat yang selama ini masih exis, dengan diterbitkan Perka BPN No. 9 tahun 2015 maka lahirlah satu jenis sertifikat baru yang disebut dengan sertifikat hak komunal. Keberadaan sertifikat hak komunal dalam bingkai hukum UUPA dan PP No. 24 Tahun 1997 merupakan konsep hukum baru yang menjawab persoalan kepastian hukum penguasaan tanah adat oleh masyarakat adat. Namun dalam tataran teori, keberadaan sertifikat hak komunal terjadi kekosongan hukum dimana sertifikat yang dikenal oleh UUPA dan PP No. 24 tahun 1997, tanah adat bukan merupakan objek pendaftaran tanah, selain itu konsep hak komunal yang tdak sesuai dengan Pasal 3 UUPA, yang hanya mengenal hak ulayat menimbulkan ketidakpastian hukum dasar hukum dari keberadaan hak komunal sebagai jenis hak baru yang diatur dalam Perka BPN No. 9 Tahun 2015.

Akibatnya pada tataran penerapan, keberadaan Perka BPN No. 9 Tahun 2015 dianggap menyalahi aturan induknya, UUPA dan PP No. 24 Tahun 1997. Olehnya itu, beradasarkan permasalahan diatas maka focus penelitian ini membahas mengenai kepastian hukum penerbitan sertifikat hak komunal sebagai pelaksanaan reforma agraria.

\section{PEMBAHASAN \& HASIL PENELITIAN}

\section{Penerbitan Sertifikat Hak Komunal}

Penerbitan sertifikat hak komunal dalam konteks reforma agrarian merupakan sebuah terobosan hukum yang dilakukan Badan Pertanahan Nasional Republik Indonesia untuk melakukan perombakan mengenai pemilikan dan penguasaan tanah serta hubungan-hubungan hukum yang bersangkutan dengan penguasaan tanah.

Fungsi penataan penguasaan tanah meliputi tugas mengawasi pembatasan penguasaan pemilikan dan penggunaan tanah untuk melaksanakan proses dalam Pasal 6 (fungsi sosial hak atas tanah), Pasal 7 (asas bahwa pemilikan/penguasaan atas tanah tidak tak terbatas), Pasal 10 (asas bahwa setiap pemilik tanah harus menggarap/mengusahakan sendiri tanahnya) dan Pasal 1 (asas bahwa Pemerintah mempunyai wewenang untuk mengambil alih dan menguasai tanah yang melebihi batas maksimum pemilikan serta membagikannya kepaa yang memerlukan). ${ }^{6}$

\footnotetext{
${ }^{6}$ Rusmadi Murad. 2013. Administrasi Pertanahan Pelaksanaan Hukum dalam Praktek. Mandar Maju. Hlm. 47
} 
Dasar hukum penyelenggaraan Penataan Penguasaan Tanah (Landreform) di samping Pasal 7, 10 dan 17 UUPA di atas, juga diatur dalam undang-Undang No. 1 Tahun 1958 (LN 1958 No. 2) Tentang Penghapusan Tanah-Tanah Partikelir jo. Peraturan Pemerintah No. 18 Tahun 1958 Tentang Pelaksanaan Undang-Undang Penghapusan Tanah Partikelir, Undang-Undang No. 56 Prp Tahun 1960 (LN 1960 No. 174) tentang Penetapan luas tanah Pertanian jo. Peraturan Pemerintah No. 224 Tahun 1961 Tentang Pelaksanaan Pembagian Tanah dan Pemberian Ganti Rugi, Undang-Undang No. 2 Tahun 1960 (LN 1960 No. 2) tentang Perjanjian Bagi Hasil.

Dalam melaksanakan tugas dan fungsi penataan penggunaan tanah (Landreform) tersebut melakukan kegiatan :

a) Pendaftaran orang-orang yang mempunyai/menguasai tanah melampuai batas maksimum yang diperbolehkan untuk satu keluarga atau tanah-tanah absentee (terkena Udang-Undang No. 56);

b) Meneliti tanah yang telah daftar di dalam daftar tersebut huruf a;

c) Menetapkan bagian-bagian tanah yang terkena landreform tersebut;

d) Melaksanakan penguasaan atas tanah yang terkena landreform dan menyatakan sebagai tanah yang dikuasai langsung oleh Negara;

e) Mengeluarkan surat izin menggarap (SIM) kepa yang berhak;

f) Mendaftar para penggarap dan menetapkan urutan prioritas penggarap yang berhak mendapatkan redistribusi berdasarkan ketentuan Peraturan Pemerintah No. 224 Tahun 1961;

g) Melakukan redistribusi;

h) Mengatur dan menyelesaikan ganti rugi kepada Negara dan kepada bekas pemilik;

i) Menyelesaikan persertitipikatan tanah-tanah hasil redistribusi dan tanah sisa milik orang-orang yang terkena redistribusi sebagai tindak lanjut berdasarkan Peraturan Pemerintah No. 10 Tahun 1961 Tentang Pendaftaran Tanah;

j) Mengatur penyelenggaraan bagi hasil;

k) Mengatur penyelesaian gadai berdasarkan Undang-Undang No. 56 Prp 1960;

1) Menegaskan proyek-proyek landreform lainnya berdasarkan ketentuan Peraturan Pemerintah No. 224 Tahun 1961.

Berdasarkan penjelasan diatas lanreform sebagai bentuk reforma agraria agar peruntukan tanah sesuai dengan pihak yang membutuhkan maka jelaslah dalam salah satu kegiatannya adalah dengan melakukan redistribusi tanah, kaitannya dengan pemanfaatan tanah adat yang dikuasai oleh masyarakat adat maka melalui program landreform ini tampak bahwa tanah 
adat yang sebelumnya itu bukan sebagai objek pendaftaran tanah dapat didaftarkan oleh masyarakat adat melalui penerbitan sertifikat hak komunal melalui Perka BPN No. 9 Tahun 2015 tentang Tata Cara Penetapan Hak Komunal Atas Tanah Masyarakat Hukum Adat dan Masyarakat Yang Berada dalam Kawasan Tertentu sebagai poin pertimbangan dari aturan tersebut yaitu:

"Bahwa untuk mewujudkan cita-cita luhur bangsa Indonesia dan mewujudkan komitmen politik yang sungguh-sungguh dalam pengelolaan sumber daya alam yang adil, berkelanjutan, dan ramah lingkungan sebagaimana diatur dalam ketetapan Majelis Permusyawaratan Rakyat Republik Indonesia No. IX/MPR/2001 tentang Pembaruan Agraria dan Pengelolaan sumber daya alam, perlu dilakukan pengkajian ulang terhadap peraturan perundang-undangan"

Prinsip pengelolaan sumber daya alam yang adil, berkelanjuran dan ramah lingkungan inilah yang mendasari landreform khususnya pada tanah adat yang dikuasai oleh masyarakat adat, redistribusi tanah disini juga memasukkan tanah adat sebagai objek dari landreform yang peruntukkan harus dibagi berdasarkan prinsip-prinsip pembaruan agrarian yang adil berkelanjutan dan ramah lingkungan. Prinsip pembaruan agrarian inilah yang kemudian dalam program landreform mulai diterapkan terhadap tanah-tanah adat melalui Perka BPN No. 9 Tahun 2015 dimana dikenal dengan penerbitan sertifikat hak komunal sebagai jaminan kepastian hukum yang diberikan oleh Negara kepada masyarakat adat atas tanah komunal

Hak komunal menurut Pasal 1 Ayat (1) Perka BPN No. 9 tahun 2015 adalah hak milik bersama atas tanah suatu masyarakat hukum adat atau hak milik bersama atas tanah yang diberikan kepada masyarakat yang berada dalam kawasan tertentu. Hak komunal berdasarkan Pasal ini memuat konsepsi kepemilikan bersama masyarakat hukum adat atas tanah. Pemberian hak komunal kepada masyarakat hukum adat hanya berada pada kawasan tertentu. ${ }^{7}$

Pada proses pengajuan sertifikat hak komunal oleh masyarakat hukum adat ditujukan kepada Bupati dan/atau walikota, dalam permohonan pengajuan sertifikat hak komunal masyarakat adat harus melampirkan :

a. Riwayat masyarakat hukum adat dan riwayat tanahnya, apabila pemohon masyarakat hukum adat;

\footnotetext{
${ }^{7}$ Pasal 1 ayat (2) Perka BPN No. 9 tahun 2015 tentang tata cara penetapan hak komunal atas tanah masyarakat hukum adat dan masyarakat yang berada dalam kawasan tertentu
} 
b. Riwayat penguasaan tanah paling kurang 10 (sepuluh) tahun atau lebih secara berturut turut, apabila pemohon masyarakat yang berada dalam kawasan tertentu;

c. Fotokopi kartu identitas atau akta pendirian koperasi, unit bagian dari desa, atau kelompok masyarakat lainnya;

d. Surat keterangan dari kepala desa atau nama lain yang serupa dengan itu.

Prasyarat tersebut harus dipenuhi oleh masyarakat hukum adat yang ingin mendapatkan sertifikat hakkomunal. Terpenuhinya syarat tersebut ditentukan oleh Tim IP4T. Pembentukan Tim IP4T dilakukan oleh di Tingkat Provinsi dibentuk oleh Gubernur, sedangkan pada tingkatan Kabupaten/Kota dibentuk oleh Bupati dan/atau walikota. Tim IP4PT merupakan tim yang melaksanakan kegiatan pendataan P4T. Invntarisasi penguasaan, pemilikan, penggunaan, dan pemanfaatan tanah yang selanjutnya disebut IP4T adalah kegiatan penataan penguasaan, pemilikan, penggunaan, dan pemanfaatan tanah, yang diolah dengan sistem informasi geografis, sehingga menghasilkan peta dan informasi mengenai penguasaan tanah oleh pemohon. ${ }^{8}$ Tugas dari Tim IP4T adalah

a. Menerima permohonan;

b. Melakukan identifikasi dan verifikasi pemohon, riwayat tanah, jenis, penguasaan, pemanfaatan dan penggunaan tanah;

c. Pemeriksaan lapangan;

d. Melakukan analisa data yuridis dan data fisik;

e. Menyampaikan laporan hasil kerja tim.

Tugas dari Tim IP4T nantinya akan menganalisis permohonan sertifikat hak komunal melalui tahapan sebagai berikut

a. Identifikasi,

b. Verifikasi

c. Pemeriksaan Lapangan

d. Analisis Data Fisik dan Data Yuridis

e. Penyampaian Laporan dan Penetapan Hak Komunal

Setelah melalui proses tersebut, apabila syarat-syarat permohonan sertifikat hak komunal dipenuhi, maka TIM IP4T mengajukan kepada Gubernur dan/atau Bupati/walikota dengan hasil sebagai berikut :

\footnotetext{
8 Pasal 1 ayat 6 Peraturan Bersama Menteri Dalam Negeri Republik Indonesia, Penteri Kehutanan Republik Indonesia, Menteri Pekerjaan Umum RI, dan Kepala BPN RI No. 79 tahun 2014, No. PB.3/Menhut-11/2014, No. 8/SKB/X/2014 tentang tata cara penyelesaian penguasaan tanah yang di dalam kawasan hutan
} 
a. Bupati/Walikota menetapkan hak komunal atas tanah untuk masyarakat hukum adat yang berada dalam kawasan tertentu, dalam hal tanah terletak pada 1 (satu) kabupaten kota;

b. Gubernur menetapkan hak komunal atas tanah untuk masyarakat hukum adat atau masyarakat yang berada dalam kawasan tertentu, dalam hal tanah terletak pada lintas kabupaten/kota;

c. Penetapan tersebut kemudian disampaikan kepada Kepala Kantor Pertanahan atau Kepala Kantor wilayah BPN untuk didaftarkan hak atas tanahnya pada kantor pertanahan setempat;

d. Sertifikat hak atas tanah yang didaftarkan sebagaimana dimksud pada ayat (2), diberikan atas nama anggota masyarakat hukum adat.

Berdasarkan penjelasan diatas dapat dijabarkan bahwasanya penerbitan sertifikat hak komunal bermula melalui permohonan hak komunal oleh masyarakat hukum adat kepada Gubarnur/Bupati/Walikota, dimana diterima atau tidaknya permohonan tersebut berada pada kewenangan Kepala Daerah yang didasarkan atas hasil kajian dari Tim IP4T. didalam laporannya, dimuat beberapa hal yaitu :

a. Ada atau tidaknya masyarakat hukum adat atau masyarakat yang berada dalam kawasan tertentu;

b. Nama pimpinan adat dan anggota masyarakat hukum adat atau nama anggota masyarakat yang berada dalam kawasan tertentu;

c. Data mengenai tanah dan riwayat pemilikan dan/atau penguasaan tanah.

Kriteria tersebut didasarkan atas pengertian masyarakat hukum adat yang diatur dalam Perka BPN No. 9 Tahun 2015, pasal 1 menyebutkan bahwa "Masyarakat hukum adat adalah sekelompok orang yang terikat oleh tatanan hukum adatnya sebagai warga bersama suatu persekutuan hukum karena kesamaan tempat tinggal ataupun dasar keturunan.

Pada pasal 3 ayat (1) mempetegas keberadaan masyarakat ditunjukan dengan prasyarakat sebagai berikut :

a. Masyarakat masih dalam bentuk paguyuban;

b. Ada kelembagaan dalam perangkat penguasa adatnya;

c. Ada wilayah hukum adat yang jelas;

d. Ada pranata dan perangkat hukum, yang masih ditaati.

Kriteria masyarakat adat atau persekutuan masyarakat adat yang diatur didalam aturan tersebut tampaknyha mengikuti doktrin popular yang dibawa 
oleh Ter Haar yang mengemukakan syarat mutlak keberadaan masyarakat adat menurut hukum adat adalah ${ }^{9}$ :

a) Tatanan kelompok yang bersifat tetap;

b) Dengan kekuasaan (penguasa) sendiri; dan

c) Kekayaan materiel dan bukan materiel sendiri.

Hazairin mengungkapkan secara tegas definisi masyarakat adat beserta contohnya yaitu ${ }^{10}$

"Masyarakat-masyarakat hukum adat seperti desa di jawa, marga di sumatera selatan, nagari di minangkabau, kuria di tapanuli, wanua di Sulawesi selatan, merupakan kesatuan masyarakat yang berdiri sendiri yaitu mempunyai kelengkapan-kelengkapan untuk sanggup berdiri sendiri yaitu mempunyai kesatuan hukum, kesatuan penguasa, dan kesatuan lingkungan hidup berdasarkan hak bersama atas tanah dan air bagi semua anggotanya. Bentuk hukum kekeluargaannya (patrilinear, matrilinear, atau bilateral) memengaruhi sistem pemerintahannya terutama berdasarkan atas pertanian, peternakan, perikanan, dan pemungutan hasil hutan dan hasil air, ditambah dengan sedikit binatang liar, pertambangan, dan kerajinan tangan. Semua anggotanya sama dalam hak dan kewajibannya. Penghidupan mereka berciri komunal, di mana gotong royong, tolong menolong, serasa dan semalu mempunyai peranan yang besar"

Dari definisi ini bentuk-bentuk masyarakat hukum atau persekutuan hukum diidentifikasikan sebagai institusi kemasyarakatan yang bersifat hukum publik (publiekrechtelijk) yang menjadi substansi bahasan dalam hukum tata Negara adat (adatstaatsrecht). Karena sifatnya yang hukum public maka penentuan masyarakat adat menurut doktrin para ahli adalah secara komulatif artinya, ada atau tidaknya masyarakat adat harus memenuhi ketiga kriteria tersebut, a) tatanan kelompok yang bersifat tetap, b) Dengan kekuasaan penguasa sendiri, c) Kekayaan Materiel bukan kekayaan sendiri. Berdasarkan hal ini maka yang disebut dengan tanah ulayat dikuasai secara bersama-sama oleh persekutuan hukum.

Berdasarkan doktrin hukum ini dan dihubungkan kriteria dari keberadaan masyarakat adat yang diatur alam pasal 3 Perka BPN No. 9 Tahun 2015 secara utuh memiliki konsep hukum yang hampir sama, dimana dalam

\footnotetext{
9 B. Ter Haar Bzn dalam Terjemahan K. Ng. Soebakti Poesponoto. 1994. Asas-asas dan Susunan Hukum Adat. Pradnya Paramita. Jakarta. Hlm. 7

${ }^{10}$ Hazairin dalam Bukunya A. Suriyaman Mustari Pide. 2014. Hukum Adat Dahulu, Kini dan Akan Datang. Prenadamedia Group. Jakarta. Hlm. 91
} 
hal kekayaan materiil yang menurut aturan tersebut disebut sebagai ada wilayah hukum yang jelas. Hal yang perlu dicermati pula adalah terkait dengan pemegang hak atas hak komunal ini. berdasarkan ketentuan yang dijelaskan diatas bahwa pemegang hak itu dapat diberikan kepada anggota masyarakat hukum adat. ${ }^{11}$ Ketentuan ini sejatinya telah mengaburkan makna dari tanah komunal yang apabila ditafsirkan berdasarkan doktrin yang ada adalah harus bersifat publik sehingga penguasaan tanah komunal sudah sepatutnya diberikan kepada Kepala Adat karena sifat tanah komunal yang publik, maka peruntukan, pemanfaatan dan penggunaan tanah komunal dikuasai secara bersama-sama dan diatur oleh Kepala Adat.

Pemberian sertifikat hak komunal atas nama anggota masyarakat adat membawa implikasi hukum kepemilikan tanah komunal telah menjadi kepemilikan individu. Kepemilikan individu melalui Pasal 13 ayat (3) Perka BPN No. 9 tahun 2015 telah merubah makna hak komunal yang dianggap sebagai hak ulayat yang bersifat hak publik. Melalui ketentuan tersebut, maka akibat hukum yang muncul dari pengaturan hak komunal yang ternyata hanya bersifat privat telah serta merta menghilangkan hakekat dari keberadaan hak ulayat yang telah diatur dalam Undang-Undang No. 5 tahun 1960 tentang peraturan-peraturan dasar pokok agrarian sebagai UU induk yang mengatur mengenai hak ulayat.

\section{Konsep Hukum Hak Komunal \& Hak Ulayat}

Keberadaan hak komunal yang diatur dalam Perka BPN No. 9 tahun 2015 memiliki konsepsi hukum yang berbeda dengan hak ulayat yang diatur dari Peraturan Bersama Menteri Dalam Negeri Republik Indonesia, Menteri Kehutanan Republik Indonesia, Menteri Pekerjaan Umum RI, dan Kepala BPN RI No. 79 tahun 2014, No. PB.3/Menhut-11/2014, No. 8/SKB/X/2014 tentang tata cara penyelesaian penguasaan tanah yang di dalam kawasan hutan, dan Perka BPN No. 5 tahun 1999 tentang Pedoman Penyelesaian masalah hak ulayat masyarakat hukum adat.

Dari ketiga aturan ini hanya Perka BPN No. 9 tahun 2015 yang menganut konsesi Hak Komunal tidak berbaning lurus dari kedua aturan sebelumnya. Apabila dicermati pengertian Hak Komunal \& Hak Ulayat dari aturan tersebut memiliki makna yang berbeda.

Menurut Pasal 1 ayat (1) Perka BPN No. 9 tahun 2015

\footnotetext{
${ }^{11}$ Pasal 13 ayat (3) Perka BPN No. 9 Tahun 2015 tentang tata cara penetapan hak komunal atas tanah masyarakat hukum adat dan masyarakat yang berada dalam kawasan tertentu
} 
"Hak Komunal adalah hak milik bersama atas tanah suatu masyarakat hukum adat atau hak milik bersama atas tanah yang diberikan kepada masyarakat yang berada dalam kawasan tertentu"

Menurut Peraturan Bersama Menteri Dalam Negeri Republik Indonesia, Menteri Kehutanan Republik Indonesia, Menteri Pekerjaan Umum RI, dan Kepala BPN RI No. 79 tahun 2014, No. PB.3/Menhut-11/2014, No. $8 / \mathrm{SKB} / \mathrm{X} / 2014$ tentang tata cara penyelesaian penguasaan tanah yang di dalam kawasan hutan

“Hak Ulayat adalah kewenangan yang menurut hukum adat dipunyai oleh masyarakat hukum tertentu atas wilayah tertentu yang merupakan lingkungan para warganya untuk mengambil manfaat dari sumber daya alam, termasuk tanah, dalam wilayah tersebut, bagi kelangsungan hidup dan kehidupannya, yang timbul dari hubungan secara lahiriah dan batiniah turun temurun dan tidak terputus antara masyarakat hukum adat tersebut dengan wilayah yang bersangkutan"

Menurut Pasal 1 ayat 1 Perka BPN No. 5 tahun 1999 tentang Pedoman Penyelesaian masalah hak ulayat masyarakat hukum adat

"Hak Ulayat adalah kewenangan yang menurut hukum adat dipunyai oleh masyarakat hukum adat tertentu atas wilayah tertentu yang merupakan lingkungan para warganya untuk mengambil manfaat dari sumber daya alam, termasuk tanah, dalam wilayah tersebut, bagi kelangsungan hidup dan kehidupannya, yang timbul dari hubungan secara lahiriah dan batiniah turun temurun dan tidak terputus antara masyarakat hukum adat tersebut dengan wilayah yang bersangkutan"

Berdasarkan pengertian dari ketiga aturan tersebut, Peraturan Bersama Menteri Dalam Negeri Republik Indonesia, Menteri Kehutanan Republik Indonesia, Menteri Pekerjaan Umum RI, dan Kepala BPN RI No. 79 tahun 2014, No. PB.3/Menhut-11/2014, No. 8/SKB/X/2014 telah mengambil konsep hukum hak ulayat yang diatur dalam Perka BPN No. 5 tahun 1999 tentang Pedoman Penyelesaian masalah hak ulayat masyarakat hukum adat. Namun dalam peraturan pelaksanaya melalui Perka BPN No. 9 tahun 2015, Hak Ulayat tersebut diubah dan disederhanakan menggunakan Hak Komunal. Padahal konsep hukum hak komunal dan hak ulayat berbeda implikasi hukumnya.

Menurut Maria S.W. Sumardjono hak komunal dan hak ulayat itu berbeda, menurutnya hak komunal dengan hak ulayat dalm permen itu hakikatnya adalah membangun fiksi hukum, karena hak ulayat dan hak komunal itu punya karakteristik yang berbeda, tetapi oleh permen dianggap 
sama. Hak ulayat itu berdimensi public sekaligus perdata. Dimensi publiknya tampak dalam kewenangan masyarakat hukum adat untuk mengatur ${ }^{12}$ :

1) Tanah/wilayah sebagai ruang hidupnya terkait pemanfaatannya termasuk pemeliharaannya;

2) Hubungan hukum antara masyarakat hukum adat dan tanahnya;

3) Perbuatan hukum terkait dengan tanah masyarakat hukum adat.

Dimensi perdata hak ulayat tampak dalam manifestasi hak ulayat sebagai kepunyaan bersama. Hak ulayat itu bukan hak atas tanah sebagaimana dalam Pasal 4 jo. Pasal 16 UUPA. Sebaliknya hak komunal atas tanah itu dimaknai sebagai hak atas tanah.

Terkait dengan konsepsi Hak Ulayat dan Hak Komunal yang berbeda konsepsinya dari peraturan yang ada, maka perlu dirujuk kepada teori hak milik antara Kaum Stoa, Thomas Aquinas dan Grotius. Para ahli hukum ini menjelaskan macam hak antara hak milik bersama dan hak milik pribadi.

Menurut Kaum Stoa, tidak ada milik pribadi secara alamiah. Menurut Cicero, harta milik hanya bisa menjadi milik pribadi "entah karena seseorang sudah lama sekali menguasainya... atau karena ia memperolehnya... entah melalui proses hukum, tawar menawar, atau pembelian, atau dengan penjatahan". Hanya melalui cara seperti ini hal tertentu yang secara alamiah merupakan milik bersama berubah status menjadi milik pribadi. Hanya dengan cara-cara tersebut di atas seseorang secara sah dapat mengklaim bahwa ia mempunyai hak atas barang-barang tertentu. Sebalinya, "kalau seseorang mengambil bagi dirinya sesuatu di luar cara tersebut, ia melanggar hukum masyarakat manusia. Dengan kata lain, hanya ada milik pribadi artifisial. Tidak ada milik pribadi yang bersifat alamiah. Sejalan dengan itu hak milik pribadi hanyalah hak artificial, sedangkan hak milik bersama adalah hak alamiah. ${ }^{13}$

Karena menurut Cicero dan filsuf-filsuf stoa lainnya, alam menetapkan agar segala sesuatu merupakan milik bersama, maka yang paling penting adalah milik bersama tersebut. Karena itu, segala sesuatu yang telah dihasilkan alam unuk digunakan secara bersama harus dipertahankan dan dihargai.

Berdasarkan teori hak milik aliran kaum stoa, dapat diketahui bahwasanya hak ulayat dan hak komunal memiliki dua sisi yang berbeda, pada konteks hak ulayat dimaknai sebagai sesuatu yang terjadi secara alamiah. Hal ini dapat dikutip dari definisi Perka BPN No. 5 tahun 1999 dan Peraturan bersama 3 (tiga) Menteri

\footnotetext{
12 Maria SW Sumardjono. 2016. Ihwal Hak Komunal atas Tanah. Digest Epistema Berkala Isu Hukum dan Keadilan Eko-Sosial Vol. 16 Hlm. 5

${ }^{13}$ A. Sonny Keraf. 1997. Hukum Kodrat Teori Hak Milik Pribadi. Penerbit Kanisius. Hlm. 54
} 


\section{temurun"}

“.............yang timbul dari hubungan secara lahiriah dan batiniah turun

Penormaan ini dapat dimaknai bahwasanya kewenangan hukum yang dimiliki oleh masyarakat hukum adat itu telah terbentuk melalui proses ilmiah sehingga itu merupakan hak alamaiah maka menurut teori hak milik aliran kaum stoa hak milik yang dimiliki oleh masyarakat hukum adat itu hak milik bersama. Sangat berbeda jauh penormaan yang dibentuk oleh Perka BPN No. 9 tahun 2015 disebutkan bahwa :

"Hak milik bersama atas tanah suatu masyarakat hukum adat atau hak milik bersama atas tanah yang diberikan kepada masyarakat adat"

Hak Komunal yang diuraikan diatas apabila ditinjau dari sisi teori hak milik oleh Kaum Stoa, Hak Komunal merupakan Hak Milik Pribadi, sebagaimana diungkapkan sebelumnya bahwa hak milik pribadi terjadi tidak secara alamiah, frasa yang digunakan dalam konsepsi hak komunal adalah tanah yang diberikan, ini artinya bahwa tanah itu dimiliki dalam hal ini yaitu Negara, melalui proses hukum "pemberian" maka terciptalah hak milik pribadi. Hak milik milik pribadi sejatinya tidak bersifat individualistis tetapi hak milik pribadi dalam semangat komunal. Thomas Aquinas dalam teori hak milik pribadi membedakan dua macam hak milik pribadi : pertama, hak memperoleh dan mengurus barang milik; kedua, hak menggunakan milik pribadi. Dalam kaitan dengan hak yang kedua, yaitu hak menggunakan, menurut Thomas manusia tidak boleh melihat barang milik sebagai pemilikan pribadi secara eksklusif, melainkan sebagai barang milik pribadi yang secara sukarela akan ia gunakan bersama dengan orang lain dan juga untuk mereka yang membutuhkannya. ${ }^{14}$

Berdasarkan Teori dari Thomas Aquinas dapat diartikan bahwa tampaknya Hak Komunal yang dimaksudkan dalam peraturan tersebut adalah hak milik pribadi yang dilain sisi tidak bersifat individualistis, tetapi hak milik pribadi dalam semangat komunal. Penegasan frasa hak milik bersama menunjukan penormaan yang digunakan dalam konsepsi hukum hak komunal bersifat individualistis tapi dalam semangat komunal.

Penjelasan dari Teori hak milik dari Thomas Aquinas dan Kaum Stoa yang memiliki cara pandang yang berbeda inilah yang menyebabkan ketidakharmonisan dan konsistensi penggunaan kata Hak Ulayat dan Hak Komunal dalam penerapannya pada Peraturan Perundang-undangan terkait dengan hak masyarakat adat atas tanah adat. Perseteruan Hak Milik, apakah bersifiat artificial atau alamiah masih menjadi perdebatan antar ahli hukum

${ }^{14}$ Ibid. hlm. 56 
membuat fungsionaris hukum masih kebingungan terkait dengan hak atas tanah yang dikuasai oleh masyarakat adat sampai saat ini. Namun teori hak milik yang dijelaskan oleh Grotius, tampak telah menjembatani antar kedua teori tersebut.

Grotius mengatakan alam atau dunia adda untuk digunakan secara bersama-sama oleh umat manusia. Maka "tidak ada... hal seperti milik pribadi dalam tatanan alamiah"dan, karena itu, "di mata alam tidak ada perbedaan dalam kepemilikan. Hak milik pribadi hanya diterima dalam pengertian hak untuk menggunakan milik bersama. Maka kalau dikatakan bahwa seseorang memiliki sesuatu, tidak lain berarti ia "mempunyai kemampuan untuk menggunakan secara tepat milik bersama (yakni, umum)" dan bukannya bahwa sesuatu menjadi miliknya" sedemikian rupa sehingga tidak mungkin menjadi milik individu lain mana pun juga". Jadi, pada awalnya hanya ada hak pakai alamiah. Menurutnya milik bersama bukanlah bahwa semua orang adalah pemilik segala barang di alam ini, melainkan bahwa semua orang boleh menggunakan barang-barang alam demi kepentingannya. ${ }^{15}$

Teori hak milik yang diungkapkan oleh Grotius menegaskan konsep yang untuh dalam hak ulayat, secara pemaknaan hak ulayat yang bersifat publik dan privat, disebut public karena tanah ulayat digunakan bersama-sama oleh masyarakat adat, disebut privat karena tanah adat dapat diatur hubungan hukum antara masyarakat adat dengan tanah adat. Pada konteks masyarakat hukum adat, penguasaan tanah / wilayah yang digunakan secara bersamasama, diperoleh wilayah menurutu pandangan masyarakat hukum adat karena alam telah menyediakan sumber daya alam sebagai pusat kehidupan. Hal yang menarik untuk dicontohkan adalah tanah-tanah ulayat yang berada di papua. Menurut masyarakat adat papua, tanah mempunyai nilai kearifan lokal yang tinggi oleh karena menurutnya, tanah merupakan "Ume", Ume secara etimologi adalah Mama atau Ibu.

Tanah adalah mama menurut perspektif masyarakat adat papua menunjukan bahwa tanah merupakan sumber kehidupan bagi masyarakat adat papua yang telah disediakan alam. Hal ini diperteg menurut pandangan Grotius mengenai komunitas asal yaitu suatu komunitas negative di mana, di bawah hukum kodrat, semua manusia mempunyai hak yang sama untuk menggunakan semua yang disediakan alam. Dalam komunitas negative, semua barang adalah milik bersama dan terbuka untuk digunakan oleh siapa saja.

Pandangan Grotius tersebut menegaskan bahwa yang diberlakukan oleh masyarakat adat di papua adalah konkritisasi pemaknaan hak milik

${ }^{15}$ Ibid. Hlm. 59 
bersama atas tanah yang disebut sebagai "Ume" menurut Grotius inilah hak sempurna yang dimiliki oleh masyarakat adat adalah saat hak milik dimaknai sebagai kemampuan untuk menggunakan secara tepat milik bersama (yakni, umum)" dan bukannya bahwa sesuatu menjadi miliknya.

Hak komunal dan/atau hak ulayat harus dipahami sebagai hak milik yang harus digunakan secara tepat maka konsepsi hukum yang digunakan sepatutnya harus mengandung unsur-unsur kepentingan umum. Pound dengan teorinya hukum sebagai social engineering adalah hukum harus mampu menata kepentingan-kepentingan agar tercapai keseimbangan yang proporsional. Manfaatnya adalah terbangunnya suatu struktur masyarakat sedemikian rupa hingga secara maksimum mencapai kepuasan akan kebutuhan dengan seminimum mungkin menghindari benturan dan pemborosan.

Kepentingan-kepentingan yang dimaksud menurut Pound terbagi menjadi tiga kategori kelompok kepentingan yaitu kepentingan umum, kepentingan sosial dan kepentingan pribadi. Kepentingan-kepentingan yang tergolong kepentingan umum, terbagi atas dua, yaitu : (a) kepentingankepentingan Negara sebagai badan hukum dalam mempertahankan kepribadian dan hakikatnya, b) kepentingan-kepentingan Negara sebagai penjaga kepentingan-kepentingan sosial. ${ }^{16}$

Muatan substansi kepentingan umum yang dimaksudkan dalam Teori Hak Milik Grotius telah ijabarkan oleh Pound melalui pembagian kategori kepentinga yang ternyata kepentingan umum bukanlah berdiri sendiri didalam Teori Pound disebukan bahwa Kepentingan umum yang dimaksudkan adalah Negara sebagai badan hukum yang harus mampu mempertahankan kepribadian dan penjaga kepentingan-kepentingan sosial. Kepentingan sosial yang dimaksudkan adalah ${ }^{17}$

a) Pertama, kepentingan sosial dalam soal keamanan umum. Ini meliputi kepentingan dalam melindungi ketenangan dan ketertiban, kesehatan dan keselamatan, keamanan atas transaksi-transaksi dan pendapatan;

b) Kedua, kepentingan sosial dalam hal keamananan institusi;

c) Ketiga, kepentingan-kepentingan sosial menyangkut moral umum. Ini meliputi perlindungan masyarakat terhadap merosotnya moral;

d) Keempat, kepentingan sosial menyangkut pengamanan sumber daya sosial. ini berkaitan dengan tuntutan yang berkaitan dengan kehidupan

\footnotetext{
${ }^{16}$ Bernard L Tanya, Yoan N. Simanjuntak, Markus Y. Hage. 2010. Teori Hukum Strategi Tertib Manusia Lintas Ruang dan Generasi. Genta Publishing. Hlm. 155

${ }_{17}^{1}$ Ibid. hlm156-157
} 
sosial dalam masyarakat beradab agar orang jangan boros dengan apa yang ada. Penyalahgunaan hak atas barang yang dapat merugikan orang lain;

e) Kelima, kepentingan sosial menyangkut kemajuan sosial. ini berkaitan dengan keterjaminan hak manusia memanfaatkan alam untuk kebutuhannya, tuntutan agar rekayasa sosial bertambah banyak dan terus bertambah baik, dan lain sebagainya;

f) Keenam, kepentingan sosial menyangkut kehidupan individual (pernyataan diri, kesempatan, kondisi kehidupan). Ini berkaitan dengan tuntutan agar tiap individu mampu menjalani kehidupannya sesuai dengan patokan-patokan masyarakat. Kepentingan inilah yang oleh Pound dilukiskan sebagai "hal yang paling penting dari semuanya".

Berdasarkan hal tersebut diatas menurut Pound, kepentingan diatas tidak bersifat absolut karena sangat tergantung pada sistem-sistem politik dan sosial suatu masyarakat/Negara. Konsepsi hukum hak komunal yang ternyata didalamnya mengandung kepentingan umum dan kemudian dijabarkan oleh Pound menjelaskan bahwa kepentingan dijalankan oleh badan hukum yang dalam hal ini adalah Negara dalam kaitan Hak Menguasa Negara yang sudah diatur dalam Pasal 33 ayat 3 UUD 1945 yang kemudian terurai dalam aturan organik yang mengatur sumber daya alam Pasal 2 UUPA yaitu :

a) Mengatur dan menyelenggarakan peruntukan, penggunaan, persediaan dan pemeliharaan bumi, air dan ruang angkasa tersebut;

b) Menentukan dan mengatur hubungan-hubungan hukum antara orangorang dengan bumi, air dan ruang angkasa;

c) Menentukan dan mengatur hubungan-hubungan hukum antara orangorang dan perbuatan-perbuatan hukum yang mengenai bumi, air dan ruang angkasa.

Hak menguasai Negara inilah yang dimiliki oleh Negara dalam mengatur kekayaan sumber daya alam di Indonesia, sehubungan dengan hal tersebut bahwa konsepsi hukum hak komunal yang lebih dekat kepada hak milik pribadi tampaknya harus dipertegas untuk tidak menyamakan dengan hak ulayat sebagaimana yang diatur dalam Pasal 3 UUPA yang hanya menyebut hak ulayat. Pengaburan norma dengan mengkonsepsikan hak komunal sebagai hak ulayat akan membuat keberadaan masyarakat hukum adat menjadi kabur sehingga keberadaan hak ulayat dan masyarakat adat menjadi kabur pula bahkan dapat dengan mudah dihilangkan.

Perubahan penguasaan hak komunal menjadi hak individu melalui proses hukum yang diberikan oleh Negara atas keberadaan tanah adat 
merupakan sebuah tindakan yang keliru dan bertentangan dengan semangat reforma agrarian yang dimaksudkan oleh UUPA. Masyarakat hukum adat tidak pernah menutup diri dari perubahan. Menurut Ter Haar perubahan masyarakat hukum adat dipengaruhi oleh perubahan-perubahan sebagai berikut :

a) Karena keinginan untuk sendiri;

b) Berkurangnya hasil hutan dan ketersediaan tanah;

c) Konflik (permusuhan) antarkerabat.

Dalam pengembaraannya meninggalkan persekuruan hukumnya, menurut Ter Haar masyarakat hukum adat menentukan dan menghadapi berbagai kondisi seperti1 ${ }^{18}$ :

a) Daerah tidak bertuan yang sudah tidak berpenghuni;

b) Masyarakat lain dengan sikap yang bersahabat atau sikap yang bermusuhan;

c) Kondisi alamiah: lembah, sungai, pulau atau daratan;

d) Faktor penentu lainnya : struktur induk masyarakat pada saat pengembaraan;

e) Faktor penentu lainnya : struktur induk masyarakat pada saat pengembaraan

f) Interaksi dengan pihak luar yang semakin intensif, mengubah kebutuhan ekonomi dan pola berpikir sehingga perubahan akan terjadi walupun lambat, tetapi pasti.

Pendapat Ter Haar ini apabila dihubungkan perkembangan masyarakat adat kekinian maka perlu ditambahkan oleh penulis bahwa perubahan yang terjadi di masyarakat juga disebabkan oleh

a) Faktor substansi hukumnya : peraturan yang mengatur mengenai masyarakat hukum adat belum berpihak kepada Hak Asasi Masyarakat Adat atas penguasaan sumber daya alam dengan menyamakan hak komunal dengan hak ulayat;

b) Penyelesaian konflik agraria masih menggunakan pendekatan konvensional melalui penyederhaan peraturan yang berkaitan dengan masyarakat adat dengan menghilangkan hakekat hak ulayat yang bersifat publik dan lebih menonjolkan sifat privat.

Perubahan masyarakat adat yang sifatnya berasal dari faktor luar inilah yang sesungguhnya akan meningkatkan angka konflik agraria di Indonesia, jaminan kepastian hukum yang diharapkan oleh masyarakat adat melalui

\footnotetext{
${ }^{18}$ A. Suriyaman Mustari Pide., op. cit., hlm. 133
} 
penerbitan sertifikat hak komunal tentu akan memunculkan berbagai permasalahan terutama yang berwenang sebagai Pemegang hak sertifikat hak komunal yang sudah tidak berada di tangan Kepala Adat (Penguasa Adat) tapi anggota masyarakat adat. Pemberian hak melalui penerbitan sertifikat hak komunal yang tidak sesuai dari semangat UUPA akan menimbulkan konflik baru antar masyarakat adat, dan secara teori antinomi norma penyusunan hak komunal masih menjadi permasalahan dalam peraturan perundang-undangan khususnya UUPA dan Peraturan Bersama Menteri Dalam Negeri Republik Indonesia, Menteri Kehutanan Republik Indonesia, Menteri Pekerjaan Umum RI, dan Kepala BPN RI No. 79 tahun 2014, No. PB.3/Menhut-11/2014, No. 8/SKB/X/2014.

Inkonsistensi pengaturan hak komunal melalui Perka BPN No. 9 tahun 2015 memunculkan ketidakpastian hukum atas pengaturan hak komunal didalamnya. Kekosongan hukum dasar hukum atas hak komunal perlu menjadi perhatian dari Pemerintah khususnya Kementrian Agraria dan Tata Ruang dalam mengatur penerbitan sertifikat hak komunal. Tentu hal ini akan membawakan keabsahan dari keberadaan sertifikat hak komunal yang merupakan sebuah terobosan hukum untuk memberikan jaminan kepastian hukum terhadap masyarakat adat dalam penguasaan sumber daya alam di Indonesia.

\section{PENUTUP}

Keberadaan sertifikat hak komunal untuk menjamin kepastian hukum atas penguasaan tanah adat oleh masyarakat adat merupakan sebuah reforma agraria melalui terobosan hukum yang progresif. Namun dalam pada tataran teori sertifikat hak komunal masih menyimpan berbagai permasalahan terutama konsepsi hukum hak komunal yang tidak berdasarkan UUPA dan Peraturan Bersama Menteri Dalam Negeri Republik Indonesia, Menteri Kehutanan Republik Indonesia, Menteri Pekerjaan Umum RI, dan Kepala BPN RI No. 79 tahun 2014, No. PB.3/Menhut-11/2014, No. 8/SKB/X/2014 Tentang Tata Cara Penyelesaian Penguasaan Tanah yang di Dalam Kawasan Hutan. Olehnya itu diharapkan perlu ada revisi konsep hukum hak komunal yang seharusnya bisa berdimensi hukum publik dan privat agar menjamin kepastian hukum atas penerbitan sertifikat hak komunal yang merupakan bagian dari reforma agraria di Indonesia.

\section{DAFTAR PUSTAKA}


A. Buku

A. Sonny Keraf. 1997. Hukum Kodrat Teori Hak Milik Pribadi. Penerbit Kanisius.

A. Suriyaman Mustari Pide. 2014. Hukum Adat Dahulu, Kini dan Akan Datang. Prenadamedia Group. Jakarta.

Bernard L Tanya, Yoan N. Simanjuntak, Markus Y. Hage. 2010. Teori Hukum Strategi Tertib Manusia Lintas Ruang dan Generasi. Genta Publishing.

Boedi Harsono. 2008. Hukum Agraria Inonesia Sejarah Pembentukan UndangUndang Pokok Agraria, Isi dan Pelaksanaannya. Penerbitan Djambaitan. Jakarta.

B. Ter Haar Bzn dalam Terjemahan K. Ng. Soebakti Poesponoto. 1994. Asasasas dan Susunan Hukum Adat. Pradnya Paramita. Jakarta.

Rusmadi Murad. 2013. Administrasi Pertanahan Pelaksanaan Hukum dalam Praktek. Mandar Maju.

Yamin Lubis \& Abd. Rahim Lubis. 2012. Hukum Pendaftaran Tanah. Penerbit CV Mandar Maju. Bandung.

\section{B. Jurnal, Opini Hukum}

Maria SW Sumardjono. 2016. Ihwal Hak Komunal atas Tanah. Digest Epistema Berkala Isu Hukum dan Keadilan Eko-Sosial Vol. 16.

Myrna Safitri. Mencari Perusak Hutan. Koran Kompas. Tertanggal 10 Maret 2015.

\section{Peraturan Per-UU}

Peraturan Bersama Menteri Dalam Negeri Republik Indonesia, Penteri Kehutanan Republik Indonesia, Menteri Pekerjaan Umum RI, dan Kepala BPN RI No. 79 tahun 2014, No. PB.3/Menhut-11/2014, No. 8/SKB/X/2014 Tentang Tata Cara Penyelesaian Penguasaan Tanah yang Di Dalam Kawasan Hutan.

Perka BPN No. 9 Tahun 2015 Tentang Tata Cara Penetapan Hak Komunal Atas Tanah Masyarakat Hukum Adat Dan Masyarakat Yang Berada Dalam Kawasan Tertentu. 